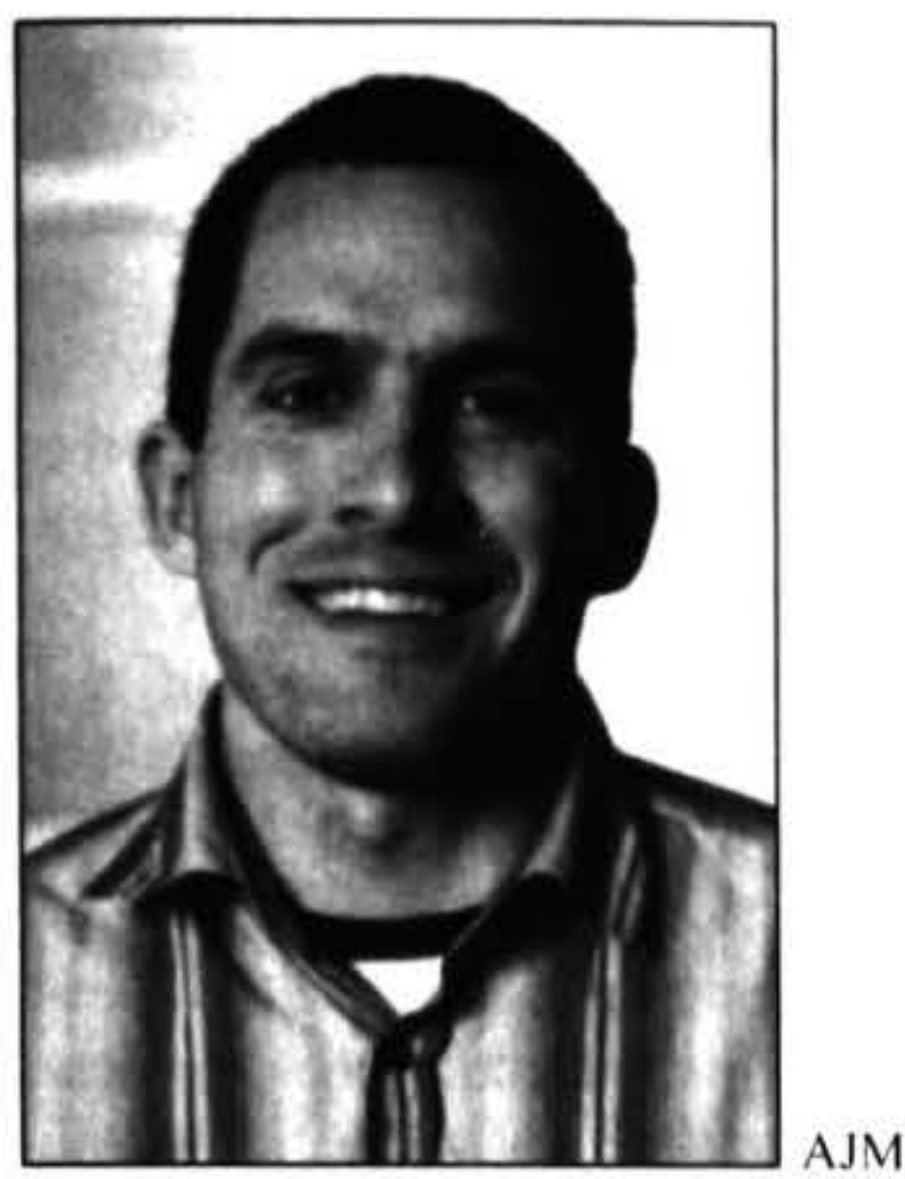

\title{
WE ARE INDEPENDENT: THE ROLE OF EMPLOYERS IN THE FORMATION OF NEW UNIONS UNDER THE EMPLOYMENT RELATIONS ACT 2000
}

\author{
Alexander John Murrie \\ School of Aviation, \\ Massey University, Palmerston North
}

$\mathrm{BF}$

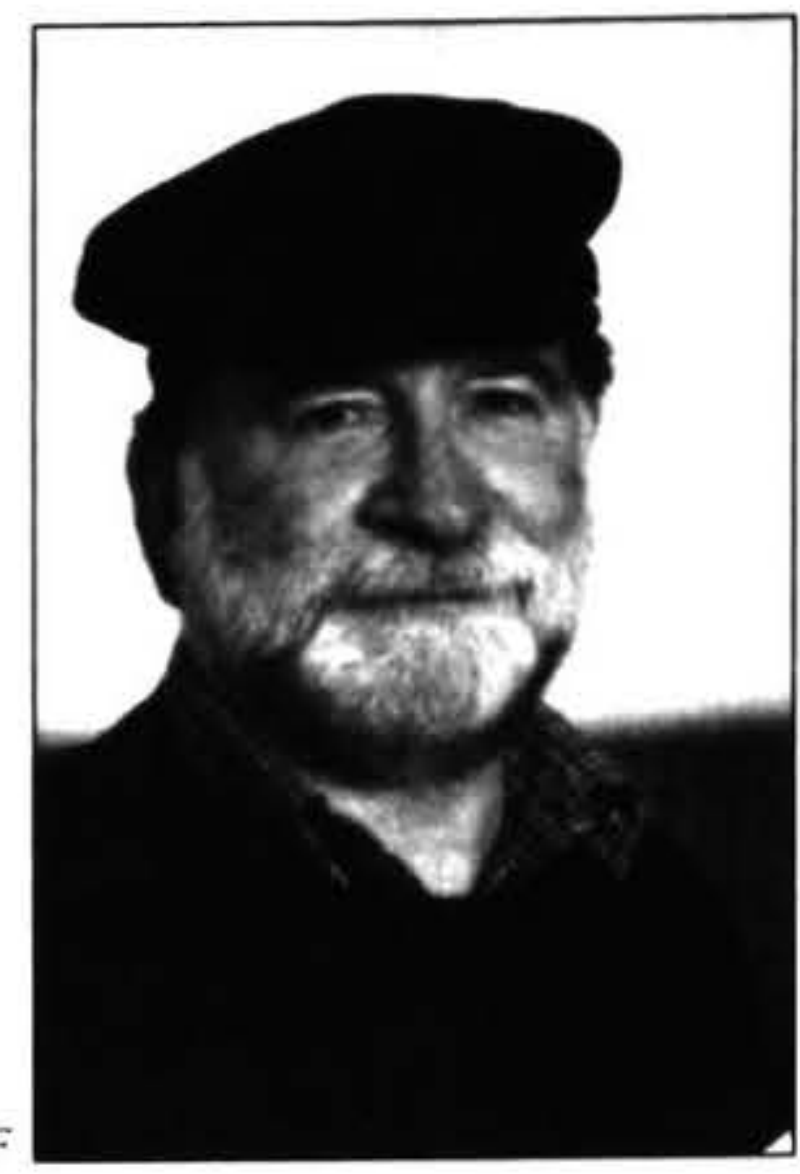

Barry Foster

Department of Human Resource

Management.

Massey University, Palmerston North

\author{
Glyn Jeffrey
}

College of Business,

Massey University, Palmerston North

\begin{abstract}
This paper reports on the formation of new: predominantly workplace based unions or New Unions under the Employment Relations Act 2000 (ERA). Specifically it quesiions whether employers actively support and facilitate the formation of New Unions and whether thev represent an indepindent form of emplovee representation. To date scholars have argued that emplovers play a significant, if not dominant, role in New Union formation that limits their ability to act independently. Some have questioned their status as gemuine unions, and implied that many represent a form of de-collectivist strategy that deliberately seeks to undermine more genuine union organisations, through the formation of tame or company unions. This paper argues that New Union formation is an emplovee driven phenomenon, and that little evidence of employers deliberately precipitating, or dominating. the formation process can be found. New Unions operate independently of employers whose involvement is more likely to reflect an acceptance of workers' legal right to organise collectively: established by the ERA, not a deliberate attempt to undermine existing unions.
\end{abstract}

\section{Introduction}

Since 2000 the New Zealand union movement has been marked by the rapid formation, registration and proliferation of new, small, enterprise-based unions (Barry, 2004; Barry \& May, 2002; Barry \& Reveley, 2001; Harbridge \& Thickett, 2003; May, 2003b) with about 100 formed within the period 2000-2004 (Employment Relations Service, 2004). This rapid growth in newly registered unions has gone against prevailing trends within Western industrialised systems (Chaison \& Rose, 1991; Freeman, 1989; Western, 1995) and nonWestern systems (Kuruvilla, Das, Kwon \& Kwon, 2002) toward a decline in union coverage and the creation, by merger, of large conglomerate union bodies (Buchanan, 2003; Chaison et al. 2001; Hose \& Rimmer, 2002).

As an organisational trend, their creation is also at odds with predictions about the potential impact of the
Employment Relations Act 2000 (ERA) on the New Zealand union movement. The more positive of these predicted that the ERA represented a turning point in New Zealand union history (May \& Walsh, 2002) that heralded a reversal of union decline, provided scope for union renewal (May, 2003a; 2003b) and fostered an environment suitable for union growth (Harbridge \& Thickett, 2003). The proliferation of so many New Unions under the ERA was an unexpected consequence of the ERA (Barry, 2004) but one that has attracted only a modest degree of interest from New Zealand scholars (Anderson, 2004; Barry, 2004; Barry \& May, 2002; Barry \& Reveley, 2001). To date existing research has focused on comparisons of new and existing union structures and interests (Barry, 2004; Barry \& May, 2002) and the possible role of employers in their formation and their use against established unions (Anderson, 2004; Barry \& Reveley, 2001). Little or no research has been found that 
addresses the motivations and interests of their membership, or the question of why they were formed.

This paper partially examines the findings of research into the formation of New Unions from 2000 - 2004.

Data was collected from semi-structured interviews with three stakeholder groups: New Unions formed under the ERA, businesses whose employees were partially or wholly represented by a New Union, and older, more established unions formed prior to the ERA. In examining New Union formation these interviews asked, "Why do New Unions form in New Zealand under the ERA?" This paper addresses findings relevant to a supporting question which asked "What role did and do employers play in workers' decision to form a union?" Existing research findings relevant to this question are presented first. followed by a discussion of relevant results from this study and points of convergence and divergence. Following this discussion the implications of these new findings for future research are considered.

\section{Previous Research}

Whether a union is capable of operating as an independent entity at arms length from (Anderson, 2004) and in pursuit of different interests to (Barry \& May, 2002) employers is a critical test of its character as a genuine union organisation (Blackburn, 1967). Yet while researchers have established independence as a key determinant of an organisation's status as a union, a lack of independence is a difficult variable to test. A lack of opposition by employers to an organisation, direct employer sponsorship of representatives on union bodies, such as consultative committees (Dundon, 2002; Royle, 2002), and possible employer financial assistance to a particular organisation (Barry, 2004; Barry \& May, 2002; Jenkins \& Sherman. 1979), have been mooted as key indicators.

Yet outside of legal definitions (Anderson, 2004), no definitive test exists to firmly establish a level of employer involvement beyond which a union's independence is and should be questioned. Employer support for the formation of New Unions is significant as it is implied to result in employer domination of a union once formed; or at least the formation of a union reluctant to oppose that employer

Confusing this issue still further is the active pursuit by many unions of formal cooperative partnerships with employers (Haynes \& Allan, 2000; Haynes \& Boxall, 2002), and the regular financial contributions of employers to unions in some countries (Fahlbeck, 2002). Partnership strategies have been observed among several countries in Europe (Haynes \& Allen, 2000; Heery, 2002), as well as North America (Rubinstein, 2001), and New Zealand (Haynes \& Boxall, 2002).

In New Zealand the independence of unions is established by a simple legislative process. All organisations seeking registration as unions submit a statutory declaration of independence to the Registrar of Unions prior to registration. It is argued that this process does little to test the reality of unions' independence as organisations (Anderson, 2004; Barry \& Reveley, 2001), presumably as it provides no evidence of the actual relationship between a union and an employer.

Determining whether New Unions, formed under the ERA, are genuine independent organisations has been a critical component of recent research in this country. To date, researchers have painted a bleak picture of the independence of many New Unions (Anderson, 2004; Barry, 2004; Barry \& May, 2002; Barry \& Reveley, 2001). It has been implied that New Unions are less independent than other, more genuine, unions on the basis of employer involvement in their formation, closer and supposedly more compliant relationships with employers, and lower membership fees (Anderson, 2004; Barry, 2004; Barry \& May, 2002).

In this vein, New Unions are indirectly described as a form of decollectivist strategy (Peetz, 2002a; 2002b) whose formation represents the interests of anti-union employers seeking to undermine the activities of, or derecognise, larger more established unions or is an attempt to reduce or prevent genuine unions from gaining an influence in particular workplaces (Barry \& May, 2002; Barry \& Reveley, 2001). The formation of new enterprise-based unions in particular said to represent:

"not... organised workers taking advantage
of organising provisions [in the ERA] but
rather vehemently anti-union employers
seeking the legitimacy of employing
unionised workers so as to challenge
further an established union" (Barry \&
Reveley: 2001.p.15).

Yet only two, of approximately 100 New Unions registered as at March 2004, have had their independence and registration challenged for these reasons. Both cases form an often quoted component of recent empirical research into unions in this country (e.g., Anderson, 2004; Barry, 2004; Barry \& May, 2002). However, by 2004 these two unions remained the only new organisations to have had their registration challenged or their independence officially questioned.'

The assumption that employers play a significant role in New Union formation contradicts some strong historical trends. Analysis of early union history describes employer action as a significant and consistent barrier to union formation (Chase, 2000; Fraser, 1999; Pelling, 1963), not as a supporting factor. Historically employer responses to workers' efforts at collectivisation could be described as predominantly negative or hostile. Employer opposition to unions was often the only method by which researchers could identify an organisation as a union (Webb \& Webb, 1907), and has become an ingrained part of many Western industrial relations systems.

Employers in these systems, particularly in Europe, have been found to pursue a complex range of covert and explicit strategies designed to undermine and/or reduce union influence and workers' desire for collective 
representation (Dundon, 2002; Logan, 2002; Peetz, 2002a \& 2002b; Royle, 2002). More specifically, employers have been shown to use a variety of strategies that undermine unions either by re-directing employee loyalty to the firm (Dundon, 2002), by challenging the legitimacy of unions (Logan, 2002), or by subverting union representational forms (Royle, 2002).

The specific methods by which these strategies are implemented, though, do offer some support for arguments that some New Unions may be an employer creation. One method has been for employers to sponsor the formation of company unions - employee bodies loyal to and controlled by an employer or at least reluctant to oppose them (Jenkins \& Sherman, 1979; Kaufman, 2000; Logan, 2002; Nissen, 1999). Company unions in the United States (Kaufman, 2000; Logan, 2002; Nissen, 1999) and white-collar staff associations in Britain (Blackburn, 1967; Jenkins \& Sherman, 1979) are key examples.

Typically, these organisations are formed by the employer, or with a significant degree of employer involvement, with the express purpose of undermining other unions (Nissen, 1999). In New Zealand the first recorded instance of employers forming a company union occurred in 1890 (Roth \& Hammond, 1981), but in this country this practice was more typically associated with the registration of an employer sponsored union under the Industrial Conciliation and Arbitration Act 1894 (Holt, 1986; Roth, 1973; Olssen, 1986).

More recently, New Unions formed under the ERA are considered to represent a new form of the company union phenomenon (Anderson, 2004; Barry, 2004; Barry \& May, 2002; Barry \& Reveley, 2001). However, little direct evidence has been provided that indicates why New Zealand employers would take such action or see it as advantageous. Undermining the collective bargaining efforts of traditional or Old Unions is mooted as one reason (Barry, 2004; Barry \& May, 2001; Barry \& Reveley, 2001). But whether employers are deliberately pursuing this type of strategy has yet to be definitively established, as outside of two or three possible extreme cases (Anderson, 2004; Barry, 2004; Barry \& May, 2001), little data has been provided that indicates the formation of company unions is a distinct phenomenon.

The formation of company unions by New Zealand employers also contradicts relevant theoretical descriptions of employer decollectivisation and management strategies in Australasia (Cullinane, 2001; Peetz 2002a; 2002b; Wright, 1997). Peetz's (2002a; 2002b) model of decollectivist strategies, for example, makes no mention of the formation of company unions as a distinct strategy. Rather it emphasises exclusive or inclusive techniques that aim to prevent unions from entering the workplace or that attempt to redirect employee loyalty toward the firm and away from unions (Peetz, 2002a; 2002b).

In New Zealand the adoption of these strategies has been found to vary according to the union density within a particular firm (Cullinane, 2001) and the impact of legislation on union organising efforts (Wright, 1997). As a key influence on unions' environment (May, 2003a), legislation has previously been used by New Zealand employers as a substitute for formal decollectivisation strategies (Wright, 1997). More specifically, in a legislative environment that was detrimental to unions, employers were found to forgo formal attempts at decollectivisation and rely on legislation to achieve similar outcomes (Wright, 1997).

While the restrictive legislative conditions to which these findings relate no longer apply, key aspects of the current legislative environment could be argued to have a decollectivising influence. Relevant factors include the absence of continued or sustained growth in union membership (Employment Relations Service, 2004), the proliferation of standardised employment agreements, and the passing on of union negotiated conditions to nonunion workers (Waldegrave, Anderson \& Wong, 2004). The use of standardised employment agreements in particular is a key facet of inclusive and exclusivist decollectivist strategies (Peetz, 2002a \& 2002b), and many New Zealand firms would appear to routinely adopt this technique (Waldegrave et al. 2004).

\section{Discussion}

Based upon existing research it was expected that employers would be found to play a supporting and principally dominant role in the formation of New Unions with the later course of action aimed at undermining existing, i.e., older, unions (Anderson, 2004; Barry, 2004; Barry \& May, 2002; Barry \& Reveley, 2001; May, $2003 \mathrm{a} ; 2003 \mathrm{~b}$ ). It was found that employers did support the formation of most, but not all, of the New Unions interviewed. Where employers supported the formation of a New Union, a typical response described that support in the following manner:
"[They - the emplover - responded] very favourably. In fact, we have an extremely. good relationship with management. I think mainly because our attitude is let's add value to the employment relationship from both sides. "

However, employer responses to the formation of New Unions were described differently by each of the three groups interviewed. The majority of New Unions in the study believed that that their employer supported, but did not assist with, their decision to form. Employers indicated that they only accepted that decision, and stated that their involvement was a matter of legislative compliance only. Old Unions responses were contradictory indicating both a strong belief in employer involvement in New Union formation, and a desire to believe that such involvement existed where it did not.

Significantly, employer support or acceptance of the formation of a New Union did not result in any form of advantage, particularly during bargaining, for those unions once formed. Again, descriptions of that relationship differed between each group interviewed. 
New Unions reported wide variations in how they interacted, and bargained, reporting advantageous, neutral and disadvantageous relationships. Employers emphasised that all unions were treated equally, with no advantage conferred to any group.

However, close relationships with employers do not necessitate a loss of independence, nor have they been found to undermine or significantly alter how workers define effective collective representation. Unionemployer partnership agreements are one example. Worker attitudes in the United States are another and reveal that a significant proportion of workers define the ideal employee organisation as one that: was jointly run by employees and management, employed representatives elected by employees and covered workers employed in similar fields (Freeman \& Rogers, 1999).

The attitudes of workers in this respect were found to be remarkably similar regardless of their membership or non-membership in a union.

Existing empirical descriptions of New Unions portray them as similar to this worker ideal. They are seen to be under a degree of management control, reliant upon employee elected representatives, based around a single enterprise or occupational group within a single enterprise.' and dependant, in part, on employers' financial support. This paper supports some of these conclusions. In particular, participant responses suggest that New Unions were seen to offer a beneficial means of communicating with management. They also emphasised workers" desire to be represented by people within their own workplace, rather than an external party. However, employers differed in their reaction to workers' decision to form a New Union.

Overall, it appears, from the perspective of New Unions that employers supported the formation of those unions as they saw it offering them some advantage or benefit. Yet while support or encouragement for the decision to form a New Union appeared strong in most, but not all, cases, the actual support provided by employers was relatively minor. Participant responses suggest that employers' actual support extended more to an absence of direct opposition to the decision to form a New Union. Significantly it was found that in some instances New Unions were formed in the face of prolonged opposition by employers to workers efforts at collectivisation.

A consistent element in existing empirical research into New Unions is the degree to which employers provided financial support to those organisations. However, receiving financial support from an employer is an accepted component of worker descriptions of the ideal employec organisation (Freeman \& Rogers, 1999), and of union-employer relationships in some countries (Fahlbeck. 2002). This paper found no evidence of employers supporting New Unions financially. However, it also found no evidence to contradict suggestions that financial support is a key part of New Union formation. Furthermore, the receipt by a union or financial assistance prior to its formation has been found to have little bearing on its ability and/or willingness to act independently once formed (Anderson, 2004; Blackburn, 1967).

Participant responses make it difficult to assert that New Union formation as a whole is an employer-driven phenomenon aimed at undermining the activities of other unions. In most cases, employer support came only after the decision to form a New Union had been made by workers. Whether this was due to employers complying with the ERA, acknowledging and supporting a staff initiative, or anticipating a long-term advantage was not clear from interviews with New Unions.

In examining employers' strategic responses to unions and union formation this paper found measured evidence of the use of techniques that duplicate key aspects of the decollectivist strategies identified by Peetz (2002a; 2002b). This included the use of standardised employment agreements, redirection of employee loyalty to the firm, and the imposition of barriers to union recruitment (Peetz, 2002a; 2002b). However, only in one instance could this influence be construed as a deliberate attempt to support or facilitate the creation of a company union. Overall, employer responses suggested, without openly acknowledging, that they influenced workers unionisation decisions by: reducing the economic value of union membership, altering the influence and image of a particular union and influencing a union's ability to service and recruit its members.

Employer descriptions of union bargaining activities, social influence and organising efforts also mirrored those provided by New Unions themselves. Most New Unions and employers in the study described their relationships as positive but not advantageous for those unions.

For some employers their key concern was actually whether employees and/or other unions believed that an "at arms length" union-employer relationship existed. A key goal was therefore to convince Older Unions that they, the employer, were not involved in, or responsible for New Union formation. This process was not assisted at times by the different behaviour or attitudes of New Unions. The absence of direct conflict between New Unions and employers commonly noted as a problem.

Old Unions, like some researchers, argued strongly however, that New Unions were heavily reliant on this type of relationship and that New Unions' long-term sustainability rested upon an unwillingness to confront or challenge an employer. Old Unions argued that this lack of conflict was also indicative of a mutual dependence between New Unions and employers, and the strong role played by employers in New Union formation. The key benefit, for employers, of sponsoring or supporting the formation of a New Union was, Old Unions, argued to be their impact on the bargaining efforts of other more genuine unions.

Old Unions, however, could offer little definitive proof of direct employee involvement in the formation of New Unions. Actual evidence of employer involvement in New Union formation remained light, with Old Union participants using the same one or two, possible extreme, 
cases as some researchers, such as the Warehouse or the Te Kuiti Beef Workers Union as evidence (Anderson, 2004; Barry, 2004; Barry \& May, 2002; Barry \& Reveley, 2001). Old Union participants further confused the issue of employer involvement when they suggested that its existence was often a matter of suspicion and belief only. One participant articulated this point quite succinctly stating that:

\begin{abstract}
"I don't think that employers are involved. even though that's what we'd like to think. it's just, I know that's what people are thinking, that's what people like to think."
\end{abstract}

\section{Conclusions}

Employers were found to play a less significant and less active role in New Union formation than previously identified (Anderson, 2004; Barry, 2004; Barry \& May, 2002; Barry \& Reveley, 2001). Specifically no evidence was found of widespread attempts by employers to sponsor or create a tame or company type union. Evidence was found, however, of possible isolated incidents, similar to those reported in existing research. Employer support for New Unions could be more appropriately described as an acceptance of workers' legal right to organise and a preference for the type and style of bargaining New Unions would pursue. Support for those unions typically did not continue postformation, and New Unions were found to operate as independent entities, albeit differently to their more established counterparts.

The primary indicator offered by employers of the presence of an 'at arm's length' relationship was the manner in which New Unions and Old Union in their organisations were treated. Employers emphasised in particular equitable treatment in collective bargaining and other aspects of their relationship with unions. New Union independence was assured, and employer duplicity in their formation avoided, by treating all unions in the same manner.

These findings suggest that scholars may have been too quick too judge the character of New Unions. While they have argued that some are genuine forms of workplace representation (Barry \& May, 2001) they have been stronger in their criticism of those unions, and for arguing that they are an employer-driven phenomenon, or at the very least incapable of becoming effective unions. The key problem for this paper and other empirical research into New Unions (Anderson, 2004; Barry, 2004; Barry \& May, 2002; Barry \& Reveley, 2001) it that none answers the question of why would an employer sponsor the formation of a New Union? More specifically, why would New Zealand employers consider it necessary and/or advantageous to do so?

A number of factors suggest that employers do not need to sponsor New Union formation particularly in order to undermine the existing union movement. Overall, the ERA, in a similar fashion to the Employment Contracts Act 1991, would appear to offer anti-union employers the opportunity to let the legislative environment decollectivise their workforces for them (Wright, 1997). Confounding the issue further is that very little is known about employer attitudes toward unions under the ERA, and consequently it is difficult to argue that some are actively attempting to deunionise their workforces. The only recent and comparable evidence is provided by studies into employer attitudes under the Labour Relations Act 1987 (McAndrew, 1989; McAndrew \& Hursthouse, 1990), and by more recent examination of their attitudes toward collective bargaining and possible role in union stagnation (Foster, Laird, McAndrew \& Murrie, 2005). A more detailed picture is provided of employers' interpretation of and response to the ERA itself, which suggests that many employers either deliberately or unwittingly serve to undermine unions (Waldegrave et al. 2004).

In short, in relation to the pursuit of formal decollectivist strategies, little evidence has been produced by this or other recent studies, to show why New Zealand employers would pursue the formation of company unions when other less overt forms of decollectivist strategy appear to be more effective. These include the use of standardised employment agreements and management strategies aimed at redirecting employee loyalty toward the firm and away from other parties (Peetz, 2002a; 2002b). There is some evidence to suggest that both are used by New Zealand employers (Cullinane. 2001: Waldegrave et al. 2004; Wright, 1997). Yet, whether this is a deliberate strategy aimed at reducing union influence is unclear.

\section{Future Research}

The findings of this paper suggest that further examination of employers' attitudes toward and response to unions under the ERA is warranted. More importantly, confusion over the actual role of employers in New Union formation argues strongly for the re-examination of the use of decollectivist strategies in New Zealand firms.

\section{Notes}

1 Information based upon personal communications with representatives of the Registrar of Unions November - December 2003.

2 Of 90 New Unions registered as at 1st March 2003, 29 possessed membership rules that restricted membership in those unions to members of a specific occupational group, typically nonmanagement personnel.

\section{References}

Anderson, G. (2004). A new unionism? The legal dimensions of union structures in New Zealand. In AIRAANZ 2004: Proceedings of the 18th Association of Industrial Relations Academics of 
Australia and New Zealand Conference. Noosa, $3^{\text {rd }}-6$ th February.

Barry, M. (2004). New employee representation: Legal developments and New Zealand unions. Emplovee Relations, 26(2), 203-223.

Barry, M. and May, R. (2002). United we stand, multiplied we fall: New unions and the New Zealand Employment Relations Act. In McAndrew, I., and Geare, A. (Eds.). AIRAANZ 2002: Proceedings of the 16th Association of Industrial Relations Academics of Australia and New Zealand Conference. Queenstown, $5^{\text {th }}-9$ th February.

Barry, M. and Reveley, J. (2001). Contradictory Rights and Unintended Consequences: The Early Impact of the Emplorment Relations Act on the New Zealand Waterfront. Working Paper 01/01. Wellington: Industrial Relations Centre, Victoria University of Wellington.

Blackburn, R.M. (1967). Union Character and Social Class. London: Batsford.

Buchanan, J. (2003). Union amalgamations as a basis for union renewal in Australia: Insights from unfinished business. Just Labour. 2. 54-64.

Chaison, G.N. and Rose, J.B. (1991). The macro determinants of union growth and decline. In Strauss, G., Gallagher, D.G., and Fiorito, J. (Eds.). The State of the Unions. Madison, Wisconsin: Industrial Relations Research Association.

Chase, M. (2000). Early Trade Unionism: Fraternitn: Skill and the Politics of Lahour. Sydney: Ashgate.

Cullinane, J. (2001). Workplace determinants of union presence in New Zealand organisations. International Journal of Manpower, 22(4), 380392.

Dundon, T. (2002). Employer opposition and union avoidance in the UK. Industrial Relations Journal, 33(3), 234-245.

Employment Relations Service. (2004). ERA Info: The Report on Emplorment Relations in Ne'w Zealand, Volume 16. Wellington: Employment Relations Service.

Fahlbeck, R. (2002). Trade unionism in Sweden. In Jose, A.V. (Ed.). Organised Labor in the 21st Century. Geneva: International Institute for Labor Studies. $63-103$

Foster, A.B., Laird, I., McAndrew, I. and Murrie, A.J. (2005). Employer's attitudes as a factor in union stagnation in New Zealand. In Referreed Conference Proceedings International Human Resource Management Conference. Cairns, Australia. 15-17 June 2005.
Franks, P. (2001). Print and Politics: A History of Trade Unions in the New Zealand Printing Industry, 1865 - 1995. Wellington: Victoria University Press.

Fraser, W.H. (1999). A History of British Trade Unionism 1700 - 1988. New York: St Martin's Press.

Freeman, R.B. and Rogers, J. (1999). What Workers Want. Ithaca, New York: Cornell University Press.

Harbridge, R. and Thickett, G. (2003). Unions in New Zealand: A retrospective. In AIRAANZ 2003: Proceedings of the 17th Association of Industrial Relations Academics of Australia and New Zealand Conference. Melbourne, $4^{\text {th }}-7^{\text {th }}$ February.

Haynes, P. and Allen, M. (2000). Partnership as union strategy: a preliminary evaluation. Employee Relations, 23(2), 164-187.

Haynes, P. and Boxall, P. (2002). Closing the Workplace Divide? Prospects for Union-Management Partnership in New Zealand. Retrieved 2nd January 2005 from www.psa.org.nz/library/ other/miscellaneous $\% 20$ papers/index.asp? sort_type $=$ Date

Heery, E. (2002). Partnership versus organising: alternative futures for British Trade Unionism. Industrial Relations Journal, 33(1), 20-35.

Holt, J. (1986). Compulsory Arbitration in New Zealand: The First Forty Years. Auckland: Auckland University Press.

Hose, K. and Rimmer, M. (2002). The Australian union merger wave revisited. The Journal of Industrial Relations, 44(4), 525-544.

Jenkins, C., and Sherman, B. (1979). White-Collar Unionism: The Rebellious Salariat. London: Routledge Keagan Paul Limited.

Kaufman, B.E. (2000). The case for the company union. Labour History, 3, 321-350.

Kuruvilla, S., Das, S., Kwon, H. and Kwon, S. (2002). Trade union growth and decline in Asia. British Journal of Industrial Relations, 40(3), 431-461.

Logan, J. (2002). Consultants, lawyers, and the union free movement in the USA since the 1970s. Industrial Relations Journal, 33(3), 197-213.

May, R. (2003a). Lahour Governments and Supportive Labour Law: Retrieved 18th August 2003 from http://www.actu.asn.au/cgi-bin/printpage /printpage.pl

May, R. (2003b). New Zealand unions in the 21st century: A review. In AIRAANZ 2003: Proceedings of the 17th Association of Industrial 
Relations Academics of Australia and New Zealand Conference. Melbourne, $4^{\text {th }}-7^{\text {th }}$ February.

May, R. and Walsh, P. (2002). Union organising in New Zealand: Making the most of the new environment? International Journal of Employment Studies, 10(2), 157-180.

McAndrew, I. (1989). Bargaining structure and bargaining scope in New Zealand: The climate of employer opinion. New Zealand Journal of Industrial Relations, 14(2), 149 -167.

McAndrew, I. and Hursthouse, P. (1990). Southern employers on enterprise bargaining. New Zealand Journal of Industrial Relations, 15, 117-128.

Nissen, B. (1999). The remarkable rehabilitation of company unionism in recent industrial relations literature. Critical Sociology, 25(1), 59 - 80.

Olssen, E. (1986). The Red Feds: Revolutionary Industrial Unionism and the New Zealand Federation of Labour 1908 - 1914. Auckland: Oxford University Press.

Peetz, D. (2002a) "You're all individuals!": Employer strategies for decollectivisation. In McAndrew, I. and Geare, A. (Eds.). AIRAANZ 2002: Proceedings of the 16th Association of Industrial Relations Academics of Australia and New Zealand Conference. Queenstown, 5th - 9th February.

Peetz, D. (2002b). Decollectivist strategies. Relations Industrielles/Industrial Relations, 57(2), 252-281.

Pelling, H. (1963). A History of British Trade Unionism (3rd Ed.). London: MacMillan Press Ltd.

Roth, H. (1973). Trade Unions in New Zealand: Past and Present. Wellington: Reed Education.

Roth, B. and Hammond, J. (1981). Toil and Trouble the Struggle for a Better Life in New Zealand. Auckland: Methuen Publications (NZ) Ltd.

Royle, T. (2002). Just vote no! Union-busting in the European fast-food industry: The case of McDonald's. Industrial Relations Journal, 33(3), 262-278.

Rubinstein, S.A. (2001). A different kind of union: Balancing co-management and representation. Industrial Relations, 40(2), 163-203.
Ryan, S.F. (1997). Men of Metal. The Amalgamated Society of Engineers Dunedin 1874 - 1923. A thesis submitted for the degree of Master of Arts in History, Otago University, New Zealand.

Waldegrave, T., Anderson, D. and Wong, K. (2003). Evaluation of the Short-Term Impacts of the Employment Relations Act 2000. Wellington: Department of Labour.

Webb, S. and Webb, B. (1907). The History of Trade Unionism (8th Ed.). London: Longmans, Green \& Co.

Western, B. (1995). A comparative study of workingclass disorganization: Union decline in eighteen advanced capitalist societies. American Sociological Review: 60, 179-201.

Wright, M.A. (1997). A Substitution Strategy for Trade Unionism? A Study Investigating Human Resource Management as a Management Approach to Employee Relations in Twenty-Two New Zealand Organisations. A thesis presented in partial fulfilment of the requirements for the degree of Master of Business Studies in Human Resource Management, Massey University.

\section{Authors}

Alexander John Murrie

Tutor

School of Aviation

Massey Univeristy

P.O. Box 11222

Palmerston North

A.J.Murrie@massey.ac.nz

Barry Foster

Lecturer

Department of Human Resource Management

Massey University

P.O. Box 11222

Palmerston North

A.B.Foster@massey.ac.nz

Glyn Jeffrey

Academic Director

College of Business

Massey University

P.O. Box 11222

Palmerston North

G.B.Jeffrey@massey.ac.nz 